\title{
Role of Viral Genotypes and Hepatitis B Viral Mutants in the Risk of Hepatocellular Carcinoma Associated with Hepatitis B and C Dual Infection
}

\author{
Chao-Hung Hung Chien-Hung Chen Chuan-Mo Lee Tsung-HuiHu \\ Sheng-Nan Lu Jing-Houng Wang Chao-Min Huang \\ Division of Hepatogastroenterology, Department of Internal Medicine, Kaohsiung Chang Gung Memorial Hospital \\ and Chang Gung University College of Medicine, Kaohsiung, Taiwan, ROC
}

\section{Key Words}

Dual hepatitis B and C. Genotype · Precore/core promoter mutation $\cdot$ Pre-S deletion $\cdot$ Hepatocellular carcinoma

\begin{abstract}
Background/Aims: The independent and interactive effects of hepatitis B virus (HBV) and hepatitis C virus (HCV) factors on the development of hepatocellular carcinoma (HCC) in chronic HBV/HCV dually-infected patients remain unclear. Methods: In a cross-sectional and case-controlled study, the HBV and HCV loads and genotypes and the sequences of pre-S and precore/core promoter regions were determined in $146 \mathrm{HCC}$ patients and 167 chronic carriers with $\mathrm{HBV} / \mathrm{HCV}$ dual infection. Results: Age (odds ratio (OR) 1.1), male sex (OR 2.3), pre-S deletion (OR 5.0), A1762T/G1764A mutant (OR 2.5), HCV genotype-1 (OR 2.4) and platelet count $<15 \times 10^{4} / \mu$ l (OR 1.9) were independently associated with HCC by stepwise logistic regression analysis. Patients with combined HBV mutations (pre-S deletion and A1762T/ G1764A mutant) and HCV genotype-1 had a 39-fold increased risk of developing $\mathrm{HCC}$ compared to those with A1762T/G1764A and pre-S wild-type strains and HCV genotype non-1. In the nested case-control study, patients with HCC had a higher HBV DNA level ( $p<0.001)$, a higher frequency of pre-S deletion $(p<0.001)$ and A1762T/G1764A mutant $(p=0.005)$, a lower HCV RNA level $(p=0.012)$ and a
\end{abstract}

\section{KARGER}

E-Mail karger@karger.com

www.karger.com/int higher prevalence of HCV genotype-1 $(p=0.002)$ than those without. Conclusions: Pre-S deletion, A1762T/G1764A mutation and HCV genotype-1 are important in hepatocarcinogenesis in chronic HBV/HCV dual infection.

Copyright $\odot 2013$ S. Karger AG, Basel

\section{Introduction}

Hepatitis B virus (HBV) and hepatitis C virus (HCV) infections are the two leading causes of chronic liver disease worldwide $[1,2]$. Both viruses are transmitted by the same routes, thus dual infection with $\mathrm{HBV}$ and $\mathrm{HCV}$ is not uncommon, accounting for $10-40 \%$ of patients with chronic hepatitis in Taiwan and Europe [3-5]. Several long-term follow-up studies, either community- or hospital-based, have clearly demonstrated the combined effect of HBV and HCV infection on the progression of chronic liver disease [6-11]. There have been numerous reports on the combined effect of chronic $\mathrm{HBV}$ and $\mathrm{HCV}$ infection on the risk of developing hepatocellular carcinoma (HCC) [9-13].

In regions endemic for $\mathrm{HBV}$ such as Asian-Pacific countries, $\mathrm{HCV}$ superinfection in individuals with chronic hepatitis $\mathrm{B}$ is the most common clinical feature of $\mathrm{HBV} / \mathrm{HCV}$ dual infection $[3,12,14-16]$. In these cases, HCV is often the dominant virus of chronic liver dis- 
ease. Previous studies in different populations worldwide have demonstrated that viral genotypes have been associated with different severity and outcome of HCVrelated liver disease [17-20]. In particular, patients infected with HCV genotype 1 have a much higher risk for HCC than those infected with HCV genotype non-1 [1720]. Therefore, it is crucial to study the role of HCV genotypes in HCC development among HBV/HCV duallyinfected patients.

In the past decade, several hepatitis B viral factors predictive of clinical outcomes have been identified [21-24]. Both case-control and cohort studies have shown a significant, dose-response association between baseline serum HBV DNA levels and the subsequent risk of liver cirrhosis and HCC during follow-up [23-25]. In addition, HBV genotype and specific naturally occurring mutants, such as basal core promoter (BCP) A1762T/ G1764A mutation, precore G1896A mutation and the deletion at the pre-S region of hepatitis B surface antigen (HBsAg), also correlate with increased risk of HCC development [22-26]. HBV has been classified into eight genotypic groups $(\mathrm{A}-\mathrm{H})$ with distinct geographical and ethnic distributions. Genotypes $\mathrm{B}$ and $\mathrm{C}$ are the most predominant variants in Asia [21, 23, 25, 26], and genotype $\mathrm{C}$ is found to be more commonly associated with severe liver diseases and HCC compared with genotype B [21, $25,26]$. It is not clear whether these viral factors also contribute to hepatocarcinogenesis in patients with dual $\mathrm{HBV} / \mathrm{HCV}$ infection, since dually-infected patients usually present with a lower level of serum HBV DNA and a different prevalence of $\mathrm{HBV}$ genotypes and precore G1896A mutation compared to those with HBV infection alone $[15,16]$.

In the present study, we thus comprehensively investigated the independent and interactive effects of each known viral factor on the development of HCC in a hospital-based, HBV/HCV dually-infected population.

\section{Patients and Methods}

\section{Patients}

The study included 313 patients with chronic HBV and HCV dual infection receiving long-term follow-up at the gastroenterologic clinics of Kaohsiung Chang Gung Memorial Hospital since January 1999. Dual infection was defined as seropositivity for both antibody to HCV (anti-HCV) and HBsAg for more than 6 months. None of these patients had coinfection with hepatitis $\mathrm{D}$ virus or human immunodeficiency virus. Patients with a history of antiviral therapy for $\mathrm{HBV}$ and/or HCV, alcoholism, drug abuse, or concomitant autoimmune hepatitis were also excluded. They included 116 chronic hepatitis, 51 cirrhosis and 146 HCC patients. Pathologic diagnoses of chronic hepatitis or cirrhosis were made by percutaneous liver biopsies $(\mathrm{n}=127)$, according to a modified Knodell histology index [27]. Fibrosis score 4 was defined as cirrhosis [27]. Clinical diagnosis of cirrhosis was based on repeated ultrasound findings suggestive of cirrhosis at least twice 3 months apart [28], supplemented with clinical criteria or other signs of portal hypertension. The diagnosis of HCC was based on the histopathologic findings in tumor tissue or the characteristic appearance of imaging studies [29]. Serum samples from each subject were stored at $-70^{\circ}$ until use. Serum samples were collected for patients with histologically verified chronic liver disease at the time when liver biopsies were performed and for HCC patients when HCC was initially diagnosed. The study protocol, which conforms to the provisions of the Declaration of Helsinki, was approved beforehand by the Human Research and Ethics committee (Institutional Review Board), and written informed consent was obtained from each patient.

\section{Serological and Virological Tests}

$\mathrm{HBsAg}$, hepatitis B e antigen ( $\mathrm{HBeAg}$ ), antibody to $\mathrm{HBeAg}$ (anti-HBe) and anti-HDV were assayed using commercially available enzyme immunoassay kits (Abbott Laboratories, North Chicago, Ill., USA). Serum HBV DNA was quantified with a sensitive polymerase chain reaction (PCR) assay (COBAS Amplicor HBV Monitor; Roche Diagnostics, Branchburg, N.J., USA), with a detectable limit of 200 copies $/ \mathrm{ml}(60 \mathrm{IU} / \mathrm{ml})$. Dilution was performed if HBV DNA levels were $>10^{6}$ copies $/ \mathrm{ml}$. HBV genotypes were determined by using the restriction fragment length polymorphism on the surface-gene sequence, amplified by PCR with nested primers, as described previously [30]. Six genotypes (A-F) of HBV could be identified by the restriction patterns of DNA fragments. To avoid false-positive results, instructions to prevent cross-contaminations were strictly followed [31], and results were considered valid only when they were consistently obtained in duplicate.

Anti-HCV was assessed using third-generation ELISA (Ax SYM HCV 3.0; Abbott Laboratories). Qualitative detection of HCV RNA was performed by a standardized qualitative reverse transcription-PCR assay (Amplicor ${ }^{\mathrm{TM}}$, Roche Diagnostics), using biotinylated primers for the 5 ' noncoding region. The lowest detection limit of this assay was 100 copies/ml (50 IU/ml). Serum HCV RNA levels were determined by a branched-DNA (b-DNA) signal amplification assay (Versant HCV RNA 3.0. Assay; Bayer Diagnostics, Emeryville, Calif., USA). This assay was a sandwich nucleic-acid hybridization procedure with a detectable limit of 3,400 copies/ml. Genotyping of HCV was performed by reverse hybridization assay (Inno-LiPA ${ }^{\mathrm{TM}} \mathrm{HCV}$ II; Innogenetics NV, Gent, Belgium) using the HCV-Amplicor products.

\section{Nested PCR and Direct Sequencing of the Precore, BCP, and}

Pre-S Regions

The precore and BCP sequences in sera were determined using nested PCR and direct sequencing, as described previously [23]. PCR was performed as follows: $96^{\circ}$ for $2 \mathrm{~min}, 94^{\circ}$ for $1 \mathrm{~min}$, $54^{\circ}$ for $1 \mathrm{~min}$, and $72^{\circ}$ for $2 \mathrm{~min}$ for 36 cycles, and finally $72^{\circ}$ for $10 \mathrm{~min}$. For the second-round PCR, $1 \mu \mathrm{l}$ of first-round PCR product was re-amplified under the same condition of the firstround reaction, except that internal primers were used. For pre$\mathrm{S}$ sequence analysis, first-round PCR primers were $5^{\prime}$-AAAAT- 
Table 1. Comparison of clinical and virological characteristics among different clinical stages of patients with chronic hepatitis $B$ and $C$ dual infection

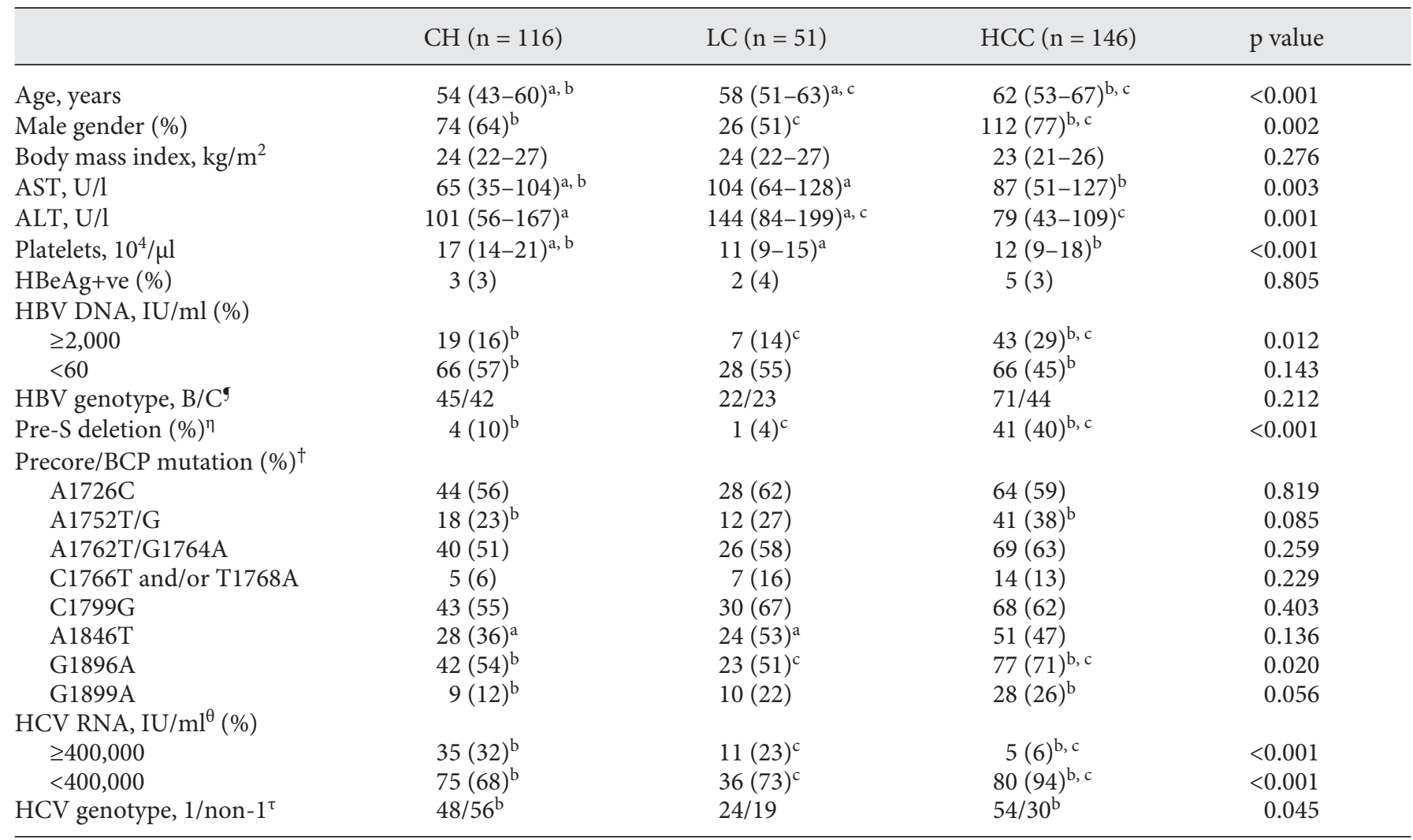

$\mathrm{CH}=$ Chronic hepatitis; $\mathrm{LC}=$ liver cirrhosis.

Data are expressed as median (interquartile range) or number (percentage). p value by one-way ANOVA test or $\chi^{2}$ test. ${ }^{a}$ Significant differences between $\mathrm{CH}$ and LC. ${ }^{\mathrm{b}}$ Significant differences $\mathrm{CH}$ and HCC. ${ }^{\mathrm{c}}$ Significant differences between LC and HCC with LSD posthoc correction. Data are available in ${ }^{\top} 247, \eta^{\eta} 166,{ }^{\dagger} 232,{ }^{\theta} 242$ and $^{\tau} 231$ patients.

TAATTATCCTGCTAGG-3' (nt 2627-2648) and 5'-GAGAAGTCCACCACGAGTC-3' (nt 269-251). PCR was performed as follows: $95^{\circ}$ for $2 \mathrm{~min}, 95^{\circ}$ for $50 \mathrm{~s}, 50^{\circ}$ for $50 \mathrm{~s}$, and $72^{\circ}$ for $2 \mathrm{~min}$ for 30 cycles, and finally $72^{\circ}$ for $7 \mathrm{~min}$. Second-round PCR primers were $5^{\prime}$-TTTACAACTCTGTGGAAGGC- $3^{\prime}$ (nt 2747-2767) and $5^{\prime}$-GAGTCTAGACTCTGTGGTATTGTG-3' (nt 255-232), and PCR condition was the same as the first-round reaction. The sensitivity of this method was 100 copies $/ \mathrm{ml}$. All necessary precautions to prevent cross-contamination were taken and negative controls were included in each assay. The nucleotide sequences of the amplified products were directly determined by using fluorescent-labeled primers with an ABI PRISM $^{\mathrm{TM}} 377$ Genetic Analyzer (Applied Biosystems, Foster City, Calif., USA).

\section{Statistical Analysis}

Continuous data are expressed as median (interquartile range) or mean $\pm \mathrm{SD}$, and the categorical data are expressed as number (percentage). Comparisons of differences in categorical data between groups were performed using the $\chi^{2}$ test. Distributions of continuous variables were analyzed by the one-way ANOVA test, Student's t test or Mann-Whitney U test where appropriate. Stepwise logistic regression analysis was performed to assess the influence of each factor on the risk of developing HCC. All analyses were carried out using SPSS software version 15.0 (SPSS, Inc., Chicago, Ill., USA). A p value $<0.05$ was considered to be statistically significant.

\section{Results}

\section{Comparison of Clinical and Virological \\ Characteristics among Different Clinical Stages of $\mathrm{HBV} / \mathrm{HCV}$ Dually-Infected Patients}

Table 1 shows the comparison of clinical and virological features among the 116 chronic hepatitis, 51 cirrhosis and 146 HCC patients. Overall, patients with HCC were 
Table 2. Univariate analyses and stepwise multivariate analyses of factors associated with the development of HCC

\begin{tabular}{|c|c|c|c|c|}
\hline & \multicolumn{2}{|c|}{ Univariate analyses } & \multicolumn{2}{|c|}{ Stepwise multivariate analyses } \\
\hline & OR (95\% CI) & $\mathrm{p}$ value & OR (95\% CI) & $\mathrm{p}$ value \\
\hline Age (per 1 year increase) & $1.1(1.0-1.1)$ & $<0.001$ & $1.1(1.0-1.1)$ & $<0.001$ \\
\hline Male gender & $2.2(1.4-3.6)$ & 0.002 & $2.3(1.2-4.4)$ & 0.010 \\
\hline Platelets, $<15 \times 10^{4} / \mu \mathrm{l}$ & $1.7(1.1-2.6)$ & 0.029 & $1.9(1.0-3.4)$ & 0.042 \\
\hline $\mathrm{HBV}$ DNA $\geq 2,000 \mathrm{IU} / \mathrm{ml}$ & $2.3(1.3-3.9)$ & 0.004 & - & - \\
\hline HBV genotype C & $0.6(0.4-1.1)$ & 0.084 & - & - \\
\hline Pre-S deletion & $7.7(2.8-20.8)$ & $<0.001$ & $5.0(1.6-15.5)$ & 0.005 \\
\hline A1726C & $1.0(0.6-1.7)$ & 0.978 & - & - \\
\hline $\mathrm{A} 1752 \mathrm{~T} / \mathrm{G}$ & $1.9(1.1-3.3)$ & 0.030 & & \\
\hline $\mathrm{A} 1762 \mathrm{~T} / \mathrm{G} 1764 \mathrm{~A}$ & $1.5(0.9-2.5)$ & 0.138 & $2.5(1.1-5.5)$ & 0.027 \\
\hline C1766T and/or T1768A & $1.4(0.6-3.1)$ & 0.458 & - & - \\
\hline C1799G & $1.1(0.7-1.9)$ & 0.637 & & \\
\hline A1846T & $1.2(0.7-2.0)$ & 0.490 & & \\
\hline G1896A & $2.2(1.3-3.7)$ & 0.006 & & \\
\hline G1899A & $1.9(1.0-3.6)$ & 0.055 & & \\
\hline HCV genotype-1 & $1.9(1.1-3.3)$ & 0.025 & $2.4(1.2-4.7)$ & 0.015 \\
\hline $\mathrm{HCV}$ RNA $\geq 4 \times 10^{5} \mathrm{IU} / \mathrm{ml}$ & $0.2(0.1-0.4)$ & $<0.001$ & & \\
\hline
\end{tabular}

significantly older and more predominantly male than were chronic hepatitis or cirrhosis. A higher serum HBV DNA level $(\geq 2,000 \mathrm{IU} / \mathrm{ml})$ was more frequently observed in HCC patients $(29 \%)$ than in those with chronic hepatitis $(16 \%)$ or cirrhosis $(14 \%)(\mathrm{p}=0.012)$. Of these patients, HBV genotypes and sequences of the precore/BCP and pre-S regions could be determined in 247 (79\%), 232 (74\%) and 166 (53\%) patients, respectively. The others failed to be determined due to undetectable viral genomes or too weak signals of PCR products for further genotyping or sequencing.

Patients with HCC had a higher frequency of pre-S deletion ( $\mathrm{p}<0.001)$ and G1896A mutation $(\mathrm{p}=0.02)$, but had a comparable prevalence of genotype C HBV as compared to those with chronic hepatitis and cirrhosis. In addition, patients with HCC had significantly lower serum HCV RNA levels $(\mathrm{p}<0.001)$ and a higher prevalence of genotype $1 \mathrm{HCV}(\mathrm{p}=0.045)$ than those without.

\section{Uni- and Multivariate Analyses of Factors Associated} with HCC Development

Table 2 shows the factors associated with the development of HCC in 313 chronic HBV/HCV dually-infected patients by uni- and multivariate analyses. Based on stepwise logistic regression analysis, age (odds ratio (OR) 1.1, $95 \%$ confidence interval (CI) $1.0-1.1 ; \mathrm{p}<0.001$ ), male sex (OR 2.3, 95\% CI 1.2-4.4; $\mathrm{p}=0.01$ ), lower platelet count $\left(<15 \times 10^{4} / \mu \mathrm{l}\right)(\mathrm{OR} 1.9,95 \%$ CI 1.0-3.4; $\mathrm{p}=0.042)$, pre-S deletion (OR 5.0, 95\% CI 1.6-15.5; $\mathrm{p}=0.005$ ), A1762T/ G1764A mutation (OR 2.5, 95\% CI 1.1-5.5; $\mathrm{p}=0.027$ ), and HCV genotype-1 (OR 2.4, 95\% CI 1.2-4.7; $\mathrm{p}=0.015$ ) were independent factors.

In subgroup analysis of old patients ( $\geq 60$ years), stepwise logistic regression analysis showed that lower platelet count $\left(<15 \times 10^{4} / \mu \mathrm{l}\right)(\mathrm{OR} 5.0,95 \%$ CI $1.6-15.4 ; \mathrm{p}=$ 0.005), pre-S deletion (OR 11.4, 95\% CI 1.7-78.5; $\mathrm{p}=0.013$ ) and HCV genotype-1 (OR 9.6, 95\% CI 2.7$34.2 ; \mathrm{p}=0.001)$ were significant factors of developing HCC. With regard to young patients ( $<60$ years), pre-S deletion (OR 3.0, 95\% CI 1.7-14.2; $\mathrm{p}=0.016$ ) and $\mathrm{A} 1762 \mathrm{~T} /$ G1764A mutation (OR 3.0, 95\% CI 1.2-7.7; $\mathrm{p}=0.021$ ) and were independent variables.

\section{Individual and Interactive Effects of Viral Factors} HBV Genotype

Although the HBV genotype was not a significant factor of developing HCC in HBV/HCV dually-infected patients, we compared the demographic and virological characteristics between HCC patients infected with different HBV genotypes. As shown in table 3, there were no differences in age, gender, serum aspartate aminotransferase (AST) and alanine transaminase (ALT) levels, platelet counts, HBV and HCV load, and HCV genotype between HBV genotype B and C patients with HCC. However, the 
Table 3. Comparison between HBV/HCV dually-infected patients with HCC infected with HBV genotype B and C

\begin{tabular}{|c|c|c|c|}
\hline & $\begin{array}{l}\text { HBV } \\
\text { genotype B } \\
(\mathrm{n}=71)\end{array}$ & $\begin{array}{l}\text { HBV } \\
\text { genotype C } \\
(\mathrm{n}=44)\end{array}$ & $\begin{array}{l}\mathrm{p} \\
\text { value }\end{array}$ \\
\hline Age, years & $60.7 \pm 12.0$ & $57.4 \pm 10.3$ & 0.136 \\
\hline Male gender (\%) & $59(83)$ & $31(70)$ & 0.087 \\
\hline AST, U/1 & $99 \pm 66$ & $105 \pm 71$ & 0.681 \\
\hline ALT, U/l & $104 \pm 116$ & $89 \pm 66$ & 0.447 \\
\hline Platelets, $10^{4} / \mu \mathrm{l}$ & $15.7 \pm 8.4$ & $13.4 \pm 7.3$ & 0.153 \\
\hline HBV DNA $\geq 2,000 \mathrm{IU} / \mathrm{ml}(\%)$ & $23(32)$ & $20(45)$ & 0.114 \\
\hline Pre-S deletion $(\%)^{\eta}$ & $21(32)$ & $20(54)$ & 0.023 \\
\hline \multicolumn{4}{|l|}{ Precore/BCP mutation $(\%)^{\dagger}$} \\
\hline A1726C & $59(88)$ & $4(10)$ & $<0.001$ \\
\hline $\mathrm{A} 1752 \mathrm{~T} / \mathrm{G}$ & $35(52)$ & $5(11)$ & $<0.001$ \\
\hline A1762T/G1764A & $37(55)$ & $31(76)$ & 0.026 \\
\hline C1766T and/or T1768A & $3(5)$ & $11(27)$ & 0.001 \\
\hline C1799G & $61(91)$ & $6(15)$ & $<0.001$ \\
\hline $\mathrm{A} 1846 \mathrm{~T}$ & $32(48)$ & $19(46)$ & 0.522 \\
\hline G1896A & $54(81)$ & $22(54)$ & 0.003 \\
\hline G1899A & $15(22)$ & $13(32)$ & 0.198 \\
\hline $\mathrm{HCV}$ RNA $\geq 400,000 \mathrm{IU} / \mathrm{ml}^{\theta}(\%)$ & $2(5)$ & $2(10)$ & 0.389 \\
\hline HCV genotype, $1 /$ non- $1^{\tau}$ & $28 / 16$ & $15 / 6$ & 0.371 \\
\hline
\end{tabular}

Data are expressed as mean \pm SD or number (percentage). $p$ value by Student's t test or $\chi^{2}$ test. Data are available in ${ }^{\eta} 103$, ${ }^{\dagger} 108,{ }^{\theta} 65$ and ${ }^{\tau} 65$ patients.

distribution of $\mathrm{HBV}$ mutants was significantly different between these two groups. Genotype C HBV had a higher frequency of pre-S deletion ( $\mathrm{p}=0.023), \mathrm{A} 1762 \mathrm{~T} / \mathrm{G} 1764 \mathrm{~A}$ mutation ( $\mathrm{p}<0.001), \mathrm{C} 1766 \mathrm{~T}$ and/or T1768A $(\mathrm{p}=0.001)$, but had a lower frequency of A1726C ( $\mathrm{p}<0.001$ ), A1752T/G ( $\mathrm{p}<0.001), \mathrm{C} 1799 \mathrm{G}(\mathrm{p}<0.001)$ and G1896A mutation $(p=0.003)$ than genotype $B$.

\section{Pre-S Deletion}

Pre-S deletion was the strongest factor associated with the development of HCC (table 2). The frequency of pre-S deletion increased from $10 \%$ in chronic carriers to $40 \%$ in patients with HCC ( $\mathrm{p}<0.001)$. Subgroup analysis showed that the association existed irrespective of age, sex, HBV load, HBV genotype, A1762T/ G1764A mutation and G1896A mutation (table 4). Nevertheless, pre-S deletion was not a significant risk factor of HCC development in patients with HCV genotype 1 (table 4).

Of the 46 patients with pre-S deletions, the variants of pre-S deletion mutants could be categorized into 6
Table 4. Pre-S deletion as a risk factor for the development of HCC in subgroup analysis

\begin{tabular}{|c|c|c|c|c|}
\hline \multirow[t]{2}{*}{ Risk factor } & \multicolumn{4}{|c|}{ Frequency of pre-S deletion } \\
\hline & $\begin{array}{l}\text { with } \\
\text { HCC }\end{array}$ & $\begin{array}{l}\text { without } \\
\text { HCC }\end{array}$ & OR $(95 \% \mathrm{CI})$ & $\begin{array}{l}\mathrm{p} \\
\text { value }\end{array}$ \\
\hline Overall & $41 / 103$ & $5 / 63$ & & \\
\hline \multicolumn{5}{|l|}{ Age, years } \\
\hline$\geq 60$ & $25 / 52$ & $2 / 14$ & $5.6(1.1-27.3)$ & 0.035 \\
\hline$<60$ & $16 / 51$ & $3 / 49$ & $7.0(1.9-26.0)$ & 0.004 \\
\hline \multicolumn{5}{|l|}{ Gender } \\
\hline Male & $33 / 82$ & $3 / 38$ & $7.9(2.2-27.7)$ & 0.001 \\
\hline Female & $8 / 21$ & $2 / 25$ & $7.1(1.3-38.4)$ & 0.023 \\
\hline \multicolumn{5}{|c|}{ HBV DNA, IU/ml } \\
\hline$\geq 2,000$ & $19 / 42$ & $1 / 15$ & $11.6(1.4-96.1)$ & 0.023 \\
\hline$<2,000$ & $22 / 61$ & $4 / 48$ & $6.2(2.0-19.6)$ & 0.002 \\
\hline \multicolumn{5}{|c|}{ HBV genotype } \\
\hline B & $21 / 66$ & $3 / 35$ & $5.0(1.4-18.1)$ & 0.015 \\
\hline $\mathrm{C}$ & $20 / 37$ & $2 / 27$ & $14.7(3.0-71.3)$ & 0.001 \\
\hline \multicolumn{5}{|c|}{$\mathrm{A} 1762 \mathrm{~T} / \mathrm{G} 1764 \mathrm{~A}$} \\
\hline Mutant & $26 / 63$ & $2 / 25$ & $8.1(1.8-37.3)$ & 0.007 \\
\hline Wild & $13 / 37$ & $3 / 37$ & $6.1(1.6-23.9)$ & 0.009 \\
\hline \multicolumn{5}{|l|}{ G1896A } \\
\hline Mutant & $26 / 71$ & $3 / 39$ & $6.9(1.9-24.8)$ & 0.003 \\
\hline Wild & $13 / 29$ & $2 / 23$ & $8.5(1.7-4.3)$ & 0.010 \\
\hline \multicolumn{5}{|c|}{ HCV genotype } \\
\hline 1 & $12 / 34$ & $3 / 23$ & $3.6(0.9-14.8)$ & 0.071 \\
\hline Non-1 & $6 / 20$ & $2 / 31$ & $6.2(1.1-34.8)$ & 0.038 \\
\hline
\end{tabular}

major types according to the deletion site [23]: type I (18 with HCC and 3 without HCC; pre-S1 deletion (N-half predominant; range aa 1-85); type II (2 with HCC and 1 without HCC; pre-S1 deletion (C-half predominant; range aa 58-118)); type III (3 with HCC; border deletion between pre-S1 and pre-S2 region (range aa 50-133)); type IV (12 with HCC; pre-S2 deletion only (range aa 120-142)); type V (4 with HCC and 1 without HCC; deleted at 2 separated sites, 1 in the pre-S1 region, the other in the pre-S2 region), and type VI (2 with HCC; unclassified). The distribution of the deleted regions was comparable between patients with and without HCC.

\section{A1762T/G1764A Mutation}

In subgroup analysis, A1762T/G1764A mutation was a significant factor of HCC development in patients with young patients ( $<60$ years), high HBV load $(\geq 2,000$ $\mathrm{IU} / \mathrm{ml}$ ), HBV genotype B and G1896A mutation, whereas this association was not significant with regard to sex, $\mathrm{HCV}$ load and genotype, and pre-S deletion. 
Table 5. Comparison between HBV/HCV dually-infected patients with and without HCC in a nested case-control study

\begin{tabular}{|c|c|c|c|}
\hline & $\begin{array}{l}\text { No HCC } \\
(\mathrm{n}=109)\end{array}$ & $\begin{array}{l}\text { HCC } \\
(\mathrm{n}=109)\end{array}$ & $\mathrm{p}$ value \\
\hline Age, years & $55.8 \pm 9.9$ & $56.3 \pm 10.1$ & matched \\
\hline Male gender (\%) & $78(72)$ & $78(72)$ & matched \\
\hline AST, U/1 & $91 \pm 61$ & $99 \pm 65$ & 0.338 \\
\hline ALT, U/l & $141 \pm 106$ & $102 \pm 104$ & 0.008 \\
\hline Platelets, $10^{4} / \mu \mathrm{l}$ & $15.3 \pm 5.3$ & $14.2 \pm 8.2$ & 0.217 \\
\hline $\mathrm{HBeAg}+\mathrm{ve}$ & $4(3.6)$ & $2(1.8)$ & 0.426 \\
\hline HBV DNA $\geq 2,000 \mathrm{IU} / \mathrm{ml}(\%)$ & $17(16)$ & $34(31)$ & 0.005 \\
\hline HBV genotype $(\mathrm{B} / \mathrm{C})^{9}$ & $50 / 35$ & $50 / 37$ & 0.490 \\
\hline Pre-S deletion $(\%)^{\eta}$ & $2(4)$ & $28(36)$ & $<0.001$ \\
\hline \multicolumn{4}{|l|}{ Precore/BCP mutation $(\%)^{\dagger}$} \\
\hline A1726C & $53(68)$ & $44(53)$ & 0.038 \\
\hline $\mathrm{A} 1752 \mathrm{~T} / \mathrm{G}$ & $22(28)$ & $30(39)$ & 0.111 \\
\hline A1762T/G1764A & $35(45)$ & $55(66)$ & 0.005 \\
\hline C1766T and/or T1768A & $9(12)$ & $11(13)$ & 0.465 \\
\hline C1799G & $5(72)$ & 49 (59) & 0.062 \\
\hline $\mathrm{A} 1846 \mathrm{~T}$ & $33(42)$ & $36(43)$ & 0.509 \\
\hline G1896A & $44(56)$ & $56(67)$ & 0.100 \\
\hline G1899A & $14(18)$ & $19(23)$ & 0.281 \\
\hline $\mathrm{HCV}$ RNA $\geq 400,000 \mathrm{IU} / \mathrm{ml}^{\theta}(\%)$ & $32(31)$ & $4(6)$ & $<0.001$ \\
\hline HCV genotype, $1 /$ non- $1^{\tau}$ & $39 / 54$ & $42 / 21$ & 0.002 \\
\hline
\end{tabular}

Data are expressed as mean \pm SD or number (percentage). $\mathrm{p}$ value by Student's t test or $\chi^{2}$ test. Data are available in 172 , $\eta 123,{ }^{\dagger} 161,{ }^{\theta} 166$ and ${ }^{\tau} 156$ patients.

\section{HCV Genotype}

There were no significant differences in clinical and virological characteristics between HCV genotype 1 and non-1 patients with HCC (data not shown). In subgroup analysis, $\mathrm{HCV}$ genotype 1 was significantly associated with a high risk of developing HCC in old patients ( $\geq 60$ years) or those with low HBV load $(<2,000 \mathrm{IU} / \mathrm{ml})$, low HCV load (<40,000 IU/ml), wild A1762T/G1764A strain or mutated G1896A.

\section{Combined Effects of Viral Factors}

We further combined three major viral factors (preS deletion, A1762T/G1764A mutation and HCV genotype-1) to examine their joint effects on the development of HCC. Compared with wild-type pre-S and A1762/ G1764 strain and HCV genotype non-1, the adjusted OR of the development of HCC was 38.5 (95\% CI 2.8-524.5; $\mathrm{p}=0.006)$ in patients with pre-S deletion, mutated A1762/ G1764 strain and HCV genotype 1 (fig. 1). Patients with

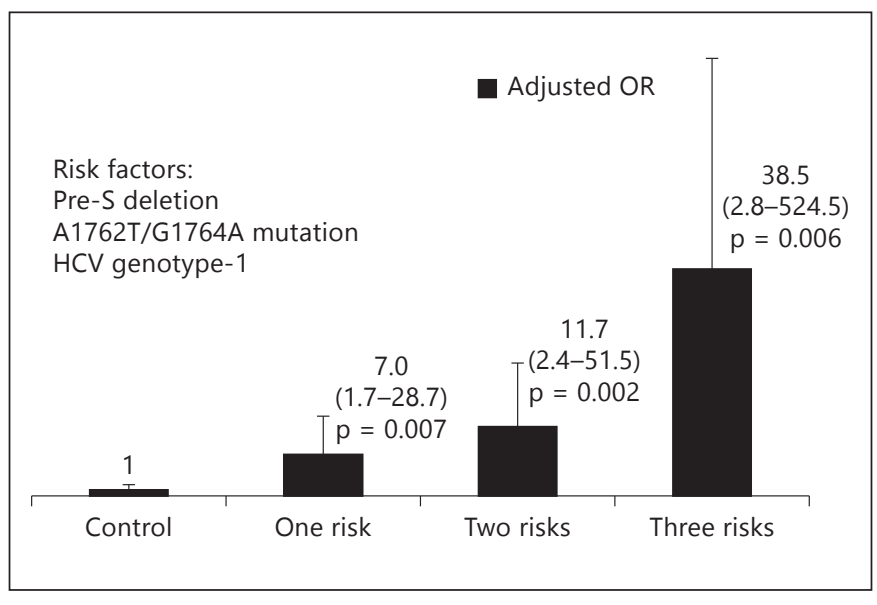

Fig. 1. Combined risk of developing HCC associated with HBV mutants and HCV genotype (analysis in 104 patients with complete data after adjusting age and sex).

any one or two of risk factors compared with patients infected with wild-type pre-S and A1762/G1764 strain and HCV genotype non-1 had a 7.0-fold (95\% CI 1.7-28.7; $\mathrm{p}=0.007)$ and 11.7 -fold (95\% CI $2.4-51.5 ; \mathrm{p}=0.002)$ increased risk of developing HCC, respectively.

\section{Comparison between HBV/HCV Dually-Infected}

Patients with and without HCC in a Case-Control

Study

We also performed an age- and sex-matched case-control study to further confirm the findings in the crosssectional study. As shown in table 5, patients with HCC had a higher HBV DNA level $(\mathrm{p}<0.001)$, a higher frequency of pre-S deletion $(\mathrm{p}<0.001)$ and A1762T/G1764A mutation $(p=0.005)$, and a higher prevalence of HCV genotype-1 $(p=0.002)$ as compared with those without HCC. Stepwise logistic regression analysis showed that pre-S deletion (OR 9.9, 95\% CI 1.4-67.8; $\mathrm{p}<0.001$ ), HCV genotype-1 (OR 6.0, 95\% CI 2.5-14.2; p < 0.001), and A1762T/G1764A mutation (OR 3.9, 95\% CI 1.5-9.9; $\mathrm{p}=$ $0.004)$ were independent factors.

\section{Discussion}

The majority of studies in Asian and Caucasian populations have provided substantial evidence suggesting that dual HBV/HCV chronic infection increases the risk of developing HCC [9-13]. However, the detailed mechanisms by which dual infection carries a higher HCC 
risk remain largely unknown. In this study, we first documented the viral mutations and genomic heterogeneity of $\mathrm{HBV}$ and $\mathrm{HCV}$ in the hepatocarcinogenesis of $\mathrm{HBV} /$ HCV dual infection. Based on the cross-sectional and nested case-control study, pre-S deletion and A1762T/ G1764A mutation of HBV and HCV genotype-1, in addition to the clinical variables, were significant factors predictive of HCC development in dual HBV/HCV infection. In particular, combined pre-S deletion, A1762T/ G1764A mutation and HCV genotype-1 had a 39-fold increased risk of developing HCC compared to pre-S and A1762T/G1764A wild-type strains and HCV genotype non-1. These findings indicated that these viral factors might serve as useful molecular markers in predicting the clinical outcomes of patients with dual HBV/ $\mathrm{HCV}$ infection.

Because the present study was cross-sectional and case-controlled, it was unclear whether these HBV mutants arose de novo or were acquired from the beginning of infection. In our previous longitudinal study, we have demonstrated that pre-S deletion and A1762T/G1764A mutation of $\mathrm{HBV}$ were independent factors significantly predictive of advanced liver disease (cirrhosis and HCC) [23]. However, proof of these hypotheses in dual HBV/ $\mathrm{HCV}$ infection would require further prospective studies or appropriate animal models.

Of note, despite their joint effects, different viral factors appear to have different impact on developing HCC between younger and elder $\mathrm{HBV} / \mathrm{HCV}$ dually-infected patients. Previous studies have shown that HBV carriers with A1762T/G1764A BCP mutation are at increased risk for HCC in both Black Africans and Asians [22, 23, $25,26]$, and A1762T/G1764A mutation may be the strongest viral factor associated with HCC risk in younger or noncirrhotic patients $[22,32]$. Our results, in agreement with these findings, suggested that A1762T/ G1764A mutation might play an important role of hepatocarcinogenesis in younger $\mathrm{HBV} / \mathrm{HCV}$ dually-infected patients. On the other hand, HCV genotype-1 was a significant factor of developing HCC in elder HBV/HCV dually-infected patients, implying that malignant transformation associated with HCV occurred as a result of longer period of inflammation and the ensuing regeneration that could enhance mutagenesis [33], although HCV genotype-1 might have higher oncogenic potential than other genotypes [34-36]. In contrast, HBV genotype $\mathrm{C}$ was not a significant factor associated with developing $\mathrm{HCC}$ in $\mathrm{HBV} / \mathrm{HCV}$ dually-infected patients. This result was compatible with those of recent studies in chronic HBV carriers, suggesting that BCP double mu- tant or pre-S deletion, rather than HBV genotype C per se, was the primary risk factor for liver cancer $[23,25]$. Since genotype C HBV had a higher frequency of pre-S deletion and A1762T/G1764A mutation, the association between HBV genotype $\mathrm{C}$ and HCC might in fact be due to the close association of HBV genotype $\mathrm{C}$ and pre-S deletion or A1762T/G1764A mutation.

Recent studies have shown that pre-S deletion mutants are highly implicated in hepatocarcinogenesis $[23,37$, 38]. The pre-S mutant large HBV surface antigens can induce oxidative stress and result in oxidative DNA damage of HBV-infected hepatocytes, which in turn leads to genomic instability and subsequent malignant transformation $[39,40]$. In our study, pre-S deletion mutant was the strongest risk factor associated with HCC development in $\mathrm{HBV} / \mathrm{HCV}$ dually-infected patients. Intriguingly, this association existed irrespective of age, sex, HBV load, HBV genotype, BCP and precore mutations, whereas pre-S deletion was not a significant factor in patients with HCV genotype 1 in subgroup analysis. Alternatively, in keeping with our previous observation in chronic HBV carriers [23], our data showed that the deleted regions were distributed randomly in the pre-S region, and no particular patterns could be identified when comparing patients with and without HCC.

As has been described by previous studies [13-16], $\mathrm{HBV} / \mathrm{HCV}$ dually-infected patients usually have a lower level of serum HBV DNA compared to those with HBV infection alone. Moreover, in this study, we found that higher hepatitis B viral loads were associated with increasing HCC risk in dually-infected patients, although this significance disappeared after multivariate analysis in the presence of other stronger risk factors. In addition, we also found an inverse correlation between serum HCV-RNA levels and the risk of developing HCC among $\mathrm{HBV} / \mathrm{HCV}$ dually-infected patients. This data supported the findings observed in our previous study enrolling patients with HCV infection alone [36]. However, controversy still exists since other reports have revealed no significant differences in serum HCV-RNA levels between chronic hepatitis $\mathrm{C}$ patients with mild and advanced liver diseases [17, 41, 42]. Taken together, our results concurred with that in a recent large cohort study [13], which has demonstrated that the highest risk of HCC is observed in those with combined high HBV load and moderate to low HCV load among HBV/HCV dually-infected patients.

This study has some potential limitations that HBV mutation data, especially the pre-S regions, were not available for all participants due to undetectable viral 
genomes or too weak signals of PCR products for further sequencing. Thus, a selection bias might have been introduced since HBV mutation data were more likely to be obtained from the participants with high hepatitis B viral load. In addition, our cohort of HBV/ $\mathrm{HCV}$ dually-infected patients was enrolled in East Asia, where genotype $\mathrm{B}$ and $\mathrm{C} \mathrm{HBV}$ and genotype 1 and 2 $\mathrm{HCV}$ are predominant $[14,16,21]$. Thus, our findings may not be generalizable to populations that are infected with other HBV and HCV genotypes. Further studies are needed to confirm the role of these viral factors on the developing HCC in the populations from other geographic areas.
In conclusion, this study showed that pre-S deletion and A1762T/G1764A mutation of HBV and HCV genotype-1 were independent risk factors for HCC in $\mathrm{HBV} /$ HCV dually-infected patients. Further work is required to understand the carcinogenic mechanisms of these viral strains, and may shed light into future therapeutics in the prevention and treatment of $\mathrm{HCC}$ associated with $\mathrm{HBV} /$ HCV dual infection.

\section{Acknowledgement}

This study was supported by Grant CMRPG880241 from Chang Gung Memorial Hospital, Taiwan.

\section{References}

$>_{1}$ Lee WM: Hepatitis B virus infection. N Engl J 12 Hung CH, Lu SN, Wang JH, et al: Sustained Med 1997;337:1733-1745.

2 World Health Organisation: Weekly epidemiological record. Wkly Epidemiol Rec 2002; 77:41-48.

3 Liaw YF: Role of hepatitis $C$ virus in dual and triple hepatitis virus infection. Hepatology 1995;22:1101-1108.

4 Ohkawa K, Hayashi N, Yuki N, et al: Hepatitis $\mathrm{C}$ virus antibody and hepatitis $\mathrm{C}$ virus replication in chronic hepatitis B patients. J Hepatol 1994;21:509-514.

5 Zarski JP, Bohn B, Bastie A, et al: Characteristics of patients with dual infection by hepatitis B and C viruses. J Hepatol 1998;28:2733.

6 Chu CM, Sheen IS, Liaw YF: The role of hepatitis $C$ virus in fulminant viral hepatitis in an endemic area of hepatitis A and B. Gastroenterology 1994;107:189-195.

7 Weltman MD, Brotodihardjo A, Crewe EB, et al: Coinfection with hepatitis B and C or B, C and $\delta$ viruses results in severe chronic liver disease and responds poorly to interferon- $\alpha$ treatment. J Viral Hepat 1995;2:39-45.

8 Hung CH, Lee CM, Lu SN, et al: Hepatic steatosis with hepatitis $B$ virus/hepatitis $C$ virus dual infection. Hepatology 2010;52:1521-1522.

$\checkmark 9$ Kaklamani E, Trichopoulos D, Tzonou A, et al: Hepatitis $B$ and $C$ viruses and their interaction in the origin of hepatocellular carcinoma. JAMA 1991;265:1974-1976.

10 Donato F, Boffetta P, Puoti M: A meta-analysis of epidemiological studies on the combined effect of hepatitis $B$ and $C$ virus infections in causing hepatocellular carcinoma. Int J Cancer 1998;75:347-354.

11 Sun CA, Wu DM, Lin CC, et al: Incidence and cofactors of hepatitis $\mathrm{C}$ virus-related hepatocellular carcinoma: a prospective study of 12,008 men in Taiwan. Am J Epidemiol 2003 157:674-682. hepatitis $\mathrm{C}$ virus clearance by interferon-based therapy reduces hepatocellular carcinoma in hepatitis B and C dually infected patients. Antivir Ther 2011;16:959-968.

13 Huang YT, Jen CL, Yang HI, et al: Lifetime risk and sex difference of hepatocellular carcinoma among patients with chronic hepatitis B and C. J Clin Oncol 2011;29:3643-3650.

14 Liu CJ, Chuang WL, Lee CM, et al: Peginterferon alfa-2a plus ribavirin for the treatment of dual chronic infection with hepatitis B and C viruses. Gastroenterology 2009;136:496504.

15 Yu ML, Lee CM, Chuang WL, et al: HBsAg profiles in patients receiving peginterferon alfa-2a plus ribavirin for the treatment of dual chronic infection with hepatitis B and C viruses. J Infect Dis 2010;202:86-92.

16 Hung $\mathrm{CH}$, Chen $\mathrm{CH}, \mathrm{Lu} \mathrm{SN}$, et al: Precore/ core promoter mutations and hepatitis $\mathrm{B}$ virus genotype in hepatitis $B$ and $C$ dually infected patients treated with interferon-based therapy. Antiviral Res 2012;93:55-63.

17 Reid AE, Koziel MJ, Aiza I, et al: Hepatitis C virus genotypes and viremia and hepatocellular carcinoma in the United States. Am J Gastroenterol 1999;94:1619-1626.

8 Ikeda K, Kobayashi M, Someya T, et al: Influence of hepatitis $\mathrm{C}$ virus subtype on hepatocellular carcinogenesis: a multivariate analysis of a retrospective cohort of 593 patients with cirrhosis. Intervirology 2002;45:71-78.

19 Bruno S, Crosignani A, Maisonneuve P, et al: Hepatitis $C$ virus genotype $1 \mathrm{~b}$ as a major risk factor associated with hepatocellular carcinoma in patients with cirrhosis: a seventeenyear prospective cohort study. Hepatology 2007;46:1350-1356.

20 Lee MH, Yang HI, Lu SN, et al: Hepatitis C virus seromarkers and subsequent risk of hepatocellular carcinoma: long-term predictors from a community-based cohort study. J Clin Oncol 2010;28:4587-4593.
21 Kao JH, Chen PJ, Lai MY, et al: Hepatitis B genotypes correlate with clinical outcomes in patients with chronic hepatitis B. Gastroenterology 2000;118:554-559.

22 Kao JH, Chen PJ, Lai MY, et al: Basal core promoter mutations of hepatitis $\mathrm{B}$ virus increase the risk of hepatocellular carcinoma in hepatitis B carriers. Gastroenterology 2003;124:327334.

23 Chen $\mathrm{CH}$, Hung $\mathrm{CH}$, Lee CM, et al: Pre-S deletion and complex mutations of hepatitis $\mathrm{B}$ virus related to advanced liver disease in $\mathrm{HBeAg}$ negative patients. Gastroenterology 2007;133 1466-1474.

24 Chen CJ, Yang HI, Su J, et al: Risk of hepatocellular carcinoma across a biological gradient of serum hepatitis B virus DNA level. JAMA 2006;295:65-73.

25 Liu CJ, Chen BF, Chen PJ, et al: Role of hepatitis B viral load and basal core promoter mutation in hepatocellular carcinoma in hepatitis B carriers. J Infect Dis 2006;193:12581265.

26 Chan HL: Significance of hepatitis B virus genotypes and mutations in the development of hepatocellular carcinoma in Asia. J Gastroenterol Hepatol 2011;26:8-12.

27 Desmet VJ, Gerber M, Hoofnagle JH, Manns M, Scheuer PJ: Classification of chronic hepatitis: diagnosis, grading and staging. Hepatology 1994;19:1513-1520.

28 Hung CH, Lu SN, Wang JH, et al: Correlation between ultrasonographic and pathologic diagnoses of hepatitis B and C virus-related cirrhosis. J Gastroenterol 2003;38:153-157.

29 Bruix J, Sherman M: Practice Guidelines Committee, American Association for the Study of Liver Diseases. Management of hepatocellular carcinoma. Hepatology 2005;42:1208-1236.

30 Mizokami M, Nakano T, Orito E, et al: Hepatitis $\mathrm{B}$ virus genotype assignment using restriction fragment length polymorphism patterns. FEBS Lett 1999;450:66-71. 
31 Kwok S, Higuchi R: Avoiding false positives with PCR. Nature 1989;339:237-238.

\$2 Liu CJ, Chen BF, Chen PJ, et al: Role of hepatitis $B$ viral load and basal core promoter mutation in hepatocellular carcinoma in hepatitis B carriers. J Infect Dis 2006;194: 594-599.

33 Kew MC, Popper H: Relationship between hepatocellular carcinoma and cirrhosis. Semin Liver Dis 1984;4:136-146.

-34 Ray RB, Lagging LM, Meyer K, et al: Hepatitis $\mathrm{C}$ virus core protein cooperates with ras and transforms primary rat embryo fibroblasts to tumorigenic phenotype. J Virol 1996;70: 4438-4443.

35 Moriya K, Fujie H, Shintani Y, et al: The core protein of hepatitis $\mathrm{C}$ virus induces hepatocellular carcinoma in transgenic mice. Nat Med 1998;4:1065-1067.
36 Hung $\mathrm{CH}$, Chen $\mathrm{CH}$, Lee CM, et al: Association of amino acid variations in the NS5A and E2-PePHD region of hepatitis $C$ virus $1 \mathrm{~b}$ with hepatocellular carcinoma. J Viral Hepat 2008; 15:58-65.

37 Abe K, Thung SN, Wu HC, et al: Pre-S2 deletion mutants of hepatitis B virus could have an important role in hepatocarcinogenesis in Asian children. Cancer Sci 2009;100:22492254.

38 Liu S, Zhang H, Gu C, et al: Associations between hepatitis $B$ virus mutations and the risk of hepatocellular carcinoma: a meta-analysis. J Natl Cancer Inst 2009;101:1066-1082.
39 Gunther S, Fischer L, Pult I, et al: Naturally occurring variants of hepatitis B virus. Adv Virus Res 1999;52:25-137.

40 Hsieh YH, Su IJ, Wang HC, et al: Pre-S mutant surface antigens in chronic hepatitis B virus infection induce oxidative stress and DNA damage. Carcinogenesis 2004;25:20232032.

41 Gretch D, Corey L, Wilson J, et al: Assessment of hepatitis $\mathrm{C}$ virus RNA levels by quantitative competitive RNA polymerase chain reaction: high-titer viremia correlates with advanced stage of disease. J Infect Dis 1994;169:12191225.

42 Kao JH, Lai MY, Chen PJ, et al: Serum hepatitis $\mathrm{C}$ virus titers in the progression of type $\mathrm{C}$ chronic liver disease. With special emphasis on patients with type $1 \mathrm{~b}$ infection. J Clin Gastroenterol 1996;23:280-283. 